$11-1-2016$

\title{
The school-based psychosocial curriculum model
}

Tracy L. Cross

College of William and Mary, tlcross@wm.edu

Jennifer Riedl Cross

College of William and Mary, jrcross@wm.edu

Lori andersen

College of William \& Mary - School of Education

Follow this and additional works at: https://scholarworks.wm.edu/educationbookchapters

Part of the Gifted Education Commons

\section{Recommended Citation}

Cross, Tracy L.; Cross, Jennifer Riedl; and andersen, Lori, "The school-based psychosocial curriculum model" (2016). School of Education Book Chapters. 13.

https://scholarworks.wm.edu/educationbookchapters/13

This Book Chapter is brought to you for free and open access by the School of Education at W\&M ScholarWorks. It has been accepted for inclusion in School of Education Book Chapters by an authorized administrator of W\&M ScholarWorks. For more information, please contact scholarworks@wm.edu. 


\title{
CHAPTER 17
}

\section{The School-Based Psychosocial Curriculum Model}

\author{
Tracy L. Cross, Jennifer Riedl Cross, \\ and Lori Andersen
}

By definition, students with gifts and talents are capable of outstanding academic achievement. Given appropriate support, they can accomplish remarkable feats. Through proper curricula, they can learn far beyond the level of their age-mates. Much attention has been given to the methods that can be used to find and nurture these exceptional intellectual abilities. For these students to fully develop their potential, they must develop their psychological and social skills as well (Subotnik, Olszewski-Kubilius, \& Worrell, 2011). Self-understanding, awareness of their needs, and cognitive and affective growth are the primary considerations in the Learning and Development Standard of the National Association for Gifted Children's (NAGC; 2010) Pre-K to Grade 12 Gifted Programming Standards, reflecting a recommendation that gifted programs should address these areas of development for students along with academic progress. Models of affective curriculum have 
incorporated a wide variety of psychological constructs, with varying definitions of the term affective (VanTassel-Baska, Cross, \& Olenchak, 2009). In this chapter, we propose a theory-driven curriculum model to support the development of psychological and social skills: the School-Based Psychosocial Curriculum Model (SPCM). We provide an overview of the foundations of the model, the elements of the model itself, and its areas of alignment and connection with the Integrated Curriculum Model (ICM) within the context of overall support for the growth and development of children with gifts and talents.

In contrast to academic curricula, we propose that affective curricula should address intrapersonal and interpersonal knowledge, beliefs, attitudes, and behaviors that contribute to students' self-understanding and acceptance; foster positive interactions with others; and enhance students' abilities to effectively approach and respond to talent development opportunities and challenges. The SPCM described here applies psychological theory to create a foundation for the development of activities that meet these objectives. At the most basic level, the groundwork for planning key activities and areas of focus within an affective curriculum lies in the important outcomes of the crises found in Erikson's (1950/1995) psychosocial theory of human developmentthe essential strengths developed from the struggle. Crick and Dodge's (1994) Social Information Processing (SIP) model offers a powerful means to make these theories applicable to learners with gifts and talents.

The SPCM is intended to be applied in schools. As such, it assumes a school-based conception of giftedness (Cross \& Coleman, 2005) in which students are identified at an early age by indicators of potential, but at later stages by their performance. Rather than taking a whole-child or gifted-child perspective, which assumes that giftedness is an entity within the student that must be identified and then served, the school-based conception suggests that all students at an early age should have opportunities to develop their potential in various talent domains. As they show signs of giftedness in this early development, their performance becomes the critical determinant of continued support from schools. Schools have limited responsibility to continue attempting to develop the talents of students who lack the motivation or perseverance to perform at an advanced level, but it is imperative that they attend early to students' psychological needs. Schools fail in their responsibility to learners when they ignore the affective components of education. When students with exceptional potential lack the psychosocial skills needed to overcome impediments to their achievement, such as resilience in the face of failure, resistance to peer pressure, and the like (Subotnik et al., 2011), it is a loss to society. To avoid this circumstance, the model discussed here can be implemented in schools to support development of the psychosocial skills required for successful talent develonment 


\section{Theoretical Foundation}

\section{Psychosocial Development}

In the study of human development, early theorists and researchers focused on changes over time in individuals. These perspectives offered considerable information about development in various domains, but a leap in our understanding came in 1950, when Erikson moved beyond Freud's (1923) immensely popular psychosexual theory of development to propose a $p s y$ chosocial theory of development. According to Erikson's (1950/1995, 1968) theory, individuals develop in relation to others, and there are ages at which certain social experiences have a significant effect, with lasting consequences to the person. He identified these crises in development as conflicts between two forces and discussed the importance of how an individual resolves each in terms of overall development. Based on his experience as a psychoanalyst and his years of observing people in multiple cultures, Erikson recognized that these crises contributed to normal or abnormal development. Attention to patients' childhood experiences of these psychosocial crises led to breakthroughs in psychoanalysis and was effective in resolving pathological issues. This theory is foundational to the SPCM.

Although children will have passed through two psychosocial crises by the time they begin preschool, we can help them "perceive the world and [themselves] correctly" (Erikson, 1968, p. 92) by attending in the SPCM to the essential strengths or basic virtues Erikson (1968) proposed as a critical outcome of the crises. Because they are advanced in other ways, it is possible that students with gifts and talents will experience some of these crises earlier than their peers.

Erikson (1950/1995) described psychosocial development as a process of integration. The crises occur at the age when circumstance and biology allow them to occur. As members of a society, all children are affected by those around them. New experiences will be filtered through past experiences. The mistrusting school-age child may have difficulty cooperating with peers. On the other hand, the totally trusting child may also have difficulty. In each of the crises, there is not a dichotomous outcome. Instead, Erikson (1950/1995) proposed that, in the process of psychosocial adaptation, all crises will result in a "favorable ratio" (p. 244) between the two forces. By emphasizing a favorable ratio between trust:mistrust, autonomy:shame and doubt, initiative:guilt, and industry:inferiority in the development of affective curriculum for students with gifts and talents, we hope to create a "mutually supportive psychosocial equilibrium" (Erikson, 1968, p. 223) that fosters students' positive identity formation and a later ability to make intimate commitments. The onus cannot 
be only on students to develop the psychosocial skills and characteristics most important to their academic success. It is also critical that their environment is molded to best support their abilities to actively master it, to express a stable personality, and to know who they are and what they should expect from the world (Jahoda, 1950, cited in Erikson, 1968). By using Erikson's stages as the framework on which to build affective curriculum, we can support them in this quest.

Erikson's (1950/1995) stage theory of psychosocial development describes a series of crises that occur as individuals enter the social world. At birth, infants enter a world that may or may not provide what they need. In the first stage of development, infants face the crisis of basic trust versus basic mistrust. Caregivers who respond to the infants' needs teach them to trust the world, but infants also come to know that their needs may not always be met. The "essential strength" (Erikson, p. 274), or "basic virtue" that is a lasting outcome of this crisis is hope. As toddlers, children become aware of their power to act on their own. In the crisis of autonomy versus shame and doubt, toddlers learn that they can take actions they desire to take, but they may be thwarted in their desire for autonomy by others, such as parents or siblings, who keep them from doing what they want to do. As they learn what they are capable of doing, "foreign overcontrol" (Erikson, p. 228) can strip them of self-assurance and create doubt in their ability to act on their own. The basic virtue resulting from a favorable ratio in the resolution of this crisis is willpower.

Preschool-aged children are capable of creating plans and acting on them. At this age, they face the crisis of initiative versus guilt. Whereas toddlers simply want to break free of others to act on their own, preschoolers are capable of involving others in their plans, imagining possibilities, and making them happen. When this initiative is struck down, either by other people or by an inability to accomplish what they can imagine, it can lead to frustration, but also guilt that they imagined something that could not be accomplished without negatively affecting or offending others or resulting in punishment (imposed by others or themselves). Erikson (1950/1995) pointed out that this is a critical stage for the building of society, because

the child is at no time more ready to learn quickly and avidly, to become bigger in the sense of sharing obligation and performance, than during this period of his development. He is eager and able to make things cooperatively, to combine with other children for the purpose of constructing and planning, and he is willing to profit from teachers and to emulate ideal prototypes. (p. 232) 
Preschools that support children's growing initiative help to create a dynamic society in which individuals work together to achieve great things. The basic virtue that is a lasting outcome of this crisis is purpose.

As they enter school age, children are learning how to work, how to be productive. In Erikson's (1950/1995) crisis of industry versus inferiority, children develop competence with the tools valued by society. Schools focus on academic skills, foundational to the production required in a developed society, although this is the time children may become good at other skills as well. When school-aged children are not successful at the skills they are attempting to learn, they can develop feelings of inferiority. This is a time when children learn to cooperate, but also to compare their abilities to those of others. They develop the basic virtue of competence through this crisis. By adolescence, children have learned who they can trust, what they can do on their own, how to take or not take initiative, and how well they can do what they are asked to do. All of these components of self-knowledge are coalescing in adolescence as they form an identity. In the crisis of identity versus role confusion, adolescents are solidifying their beliefs about themselves and integrating these beliefs with their values and ideals to create a reliable notion of who they are at all places and times. This sense of "continuity and sameness" (p. 235) may be difficult for some to achieve, creating feelings of imbalance and confusion. The outcome of a favorable ratio between identity and role confusion is the basic virtue of fidelity.

As individuals come to know who they are, they are prepared to engage in committed, intimate relationships. From a romantic partner to an organized institution (e.g., a sports club, a protest movement, a church or religion), true commitment requires sacrifice. In the crisis of intimacy versus isolation (Erikson, 1950/1995), young adults must find a favorable ratio between commitment to another (or others) and the separation that would come from not engaging fully in such relationships. The essential strength to come from this crisis is love.

In his psychoanalytic practice, Erikson (1950/1995) observed in his patients what he called "residue" from earlier crises. When they had passed through a crisis with an unfavorable ratio (e.g., too much trust or too much guilt), he could see it in their presenting clinical problems. A lack of autonomy as a toddler might result in an adult determined to "get away with things, unseen" (Erikson, p. 227) or one with "paranoic fears concerning hidden persecutors" (Erikson, p. 228). By identifying the residue of unfavorable ratios in earlier crises, targeted treatments could be undertaken to assist in more balanced psychosocial perspectives. Whereas Erikson addressed his patients' psychological difficulties through psychoanalysis, the SPCM is a tool to support the well-being of learners with gifts and talents in schools. Not intended as 
a treatment, the SPCM will use knowledge, transmitted through lessons, to assist students in developing, maintaining, or modifying to a favorable ratio between the positive and negative components of each crisis.

In schools, we are in a position to bolster positive development. As institutions of society, schools must transmit values that are consistent with the favorable ratio at the individual level. For example, students must know they are in a place in which they can trust and be trusted. They must be able to act autonomously, within boundaries, and they must have opportunities to learn what they are capable of learning. Identity develops from the relationship between society and the individual:

$[\mathrm{B}]$ asic social and cultural processes can only be viewed as the joint endeavor of adult egos to develop and maintain, through joint organization, a maximum of conflict-free energy in a mutually supportive psychosocial equilibrium. Only such organization is likely to give consistent support to the egos of growing and grown beings at every step of their development. (Erikson, 1968, p. 223; [italics in original])

An affective curriculum that acknowledges this joint endeavor will foster the development of critical psychosocial skills.

\section{Social Information Processing (SIP)}

In every social situation, an individual must process information before acting. In their Social Information Processing Model (see Figure 17.1), Crick and Dodge (1994) described in detail how the processes that they proposed underpin all social behavior. SIP is a development of the computer age, built on an information processing model. In every social situation, individuals engage in the following processes: "(1) encoding of external and internal cues, (2) interpretation and mental representation of those cues, (3) clarification or selection of a goal, (4) response access or construction, (5) response decision, and (6) behavioral enactment" (p. 76). At each step lies the potential for misinterpretation or the production of an inappropriate response. The individual's database of accumulated knowledge is critical. Prior knowledge serves as a filter, with an influence on the outcome of all steps of the SIP. The SIP has been an effective basis for programs designed to intervene with aggressive youths or those with conduct disorders (e.g., Conduct Problems Prevention Research Group, 2004; Kazdin, 2003; Lochman \& Wells, 2004).

In the SPCM, this process may be a vehicle for content delivery at the individual level and within groups and classes. Nearly every component of education involves social interaction. Teachers greet and call on students, hand out 


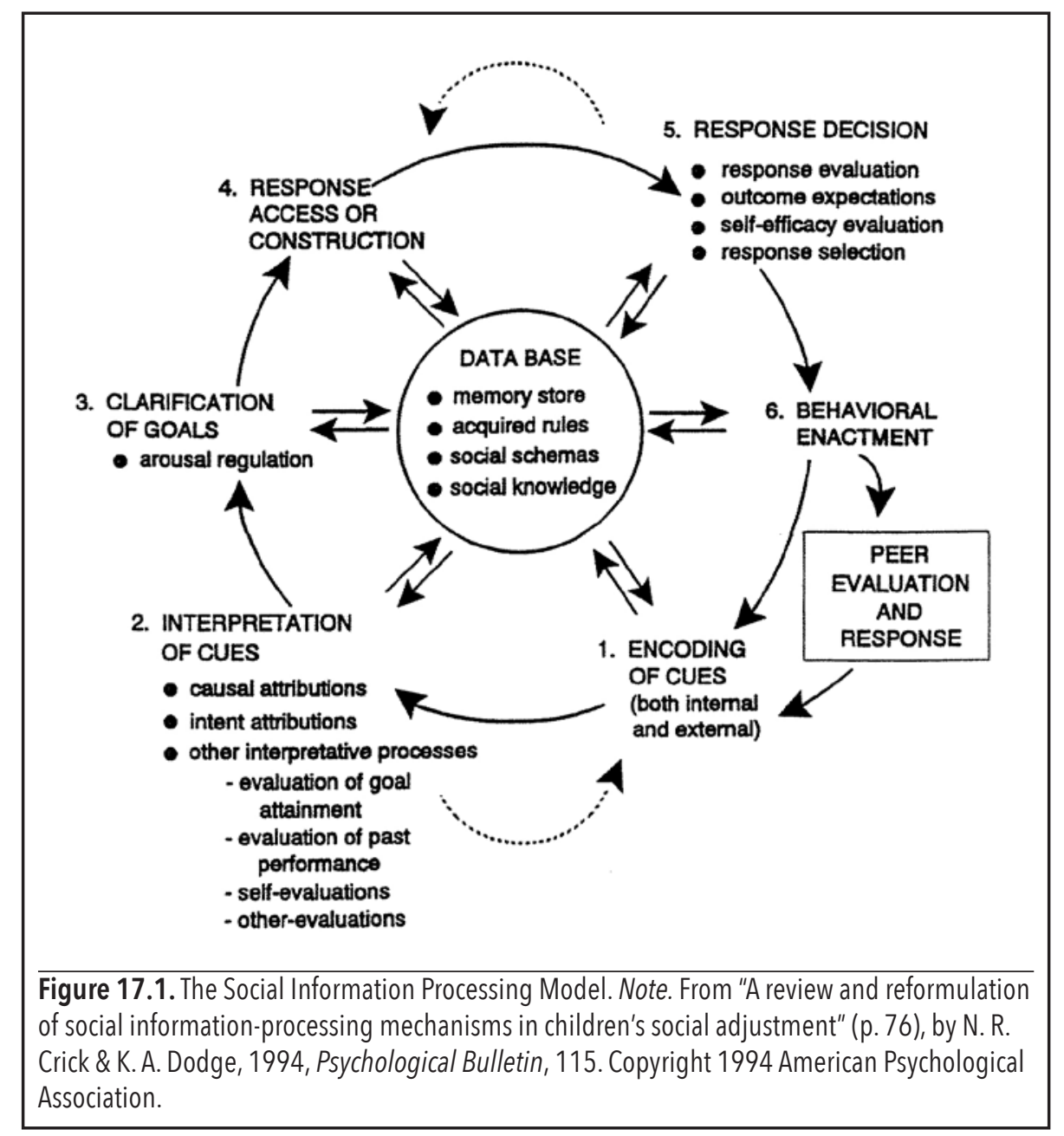

and grade assignments, choose groups, and so forth. Peers are ever present in schools, constantly interacting, judging, and comparing. Students' databases include all aspects critical to ideal affective curriculum: their intrapersonal and interpersonal knowledge, beliefs, and attitudes; and their repertoire of behaviors for dealing with others that lead to acceptance or rejection, including the response of those who contribute to their talent development. By building a curriculum on the SIP, students' own goals and their responses to talent development opportunities and challenges are topics that can be explored in depth. 


\section{The School-Based Psychosocial Curriculum Model (SPCM)}

As stated previously, the purposes of the SPCM are to

1. address intrapersonal and interpersonal knowledge, beliefs, attitudes, and behaviors that contribute to students' self-understanding and acceptance;

2. foster positive interactions with others; and

3. enhance students' abilities to effectively approach and respond to talent development opportunities and challenges.

The essential strengths resulting from the first six of Erikson's (1950/1995) eight stages of the life cycle provide the foundation for a curriculum that meets these objectives. Each crisis suggests potential topics for study and can guide the creation of lessons to bolster knowledge about the self and one's social context. Table 17.1 describes some of these topics in relation to each crisis. The favorable ratio learners can achieve between the positive and negative forces of each crisis is conceived of in the SPCM as the balance created from intra- and interpersonal experiences, as reflected in the central two columns in Table 17.1. Of these two columns, the one on the left reflects experiences that are primarily internal and about the self (psycho-). On the right are interpersonal experiences that reflect a growing knowledge of others and one's relationship to them (-social). Table 17.1 includes topics that could be developed into lessons contributing to the strengths of hope, willpower, purpose, competence, fidelity, and love. These essential strengths, or basic virtues as Erikson has called them, are the defining categories of the SPCM. Lessons should be age-appropriate, but not tied to the proposed ages of Erikson's stages, as will be elaborated later. For this reason, although Table 17.1 lists approximate ages of each crisis as related to Erikson's theory, the ages should be viewed as representing typical learners and not necessarily those with gifts and talents.

Cultivating hope. To support students' sense of trust in the world, while maintaining a healthy mistrust when appropriate, it is critical that they learn about resources. On what internal resources can they always rely? Students who recognize their role in talent development, their ability to pursue things they care about, and other personal characteristics will know what they can trust in themselves. Learning how to soothe themselves during stressful times or how to talk themselves out of negative mindsets can boost hope that they can effect a positive outcome in their lives. On the interpersonal side, students can learn what resources are available to them and what barriers in their environment may hinder them. Individuals who support them can be trusted. Nonsupporters may need to be held at arm's length. Outsiders who can support them in times of need include family members, peers, or professionals. 
TABLE 17.1

\section{Possible Lessons From Issues and Themes Suggested by Erikson's Psychosocial Crises}

\begin{tabular}{|c|c|c|c|}
\hline $\begin{array}{l}\text { Essential } \\
\text { Strength }\end{array}$ & $\begin{array}{l}\text { Crisis-Positive } \\
\text { (Intrapersonal) }\end{array}$ & $\begin{array}{l}\text { Crisis-Negative } \\
\text { (Interpersonal) }\end{array}$ & $\begin{array}{l}\text { Approximate Age } \\
\text { of Initial Crisis }\end{array}$ \\
\hline \multirow[t]{4}{*}{ Hope } & Trust & Mistrust & Birth to 1 year \\
\hline & Identify internal resources & $\begin{array}{l}\text { Identify resources and } \\
\text { barriers (e.g., supporters and } \\
\text { nonsupporters) }\end{array}$ & \\
\hline & Self-soothing & Counseling & \\
\hline & Self-talk & Counseling & \\
\hline \multirow[t]{3}{*}{ Willpower } & Autonomy & Shame and Doubt & 1 to 3 years \\
\hline & Persistence & Letting go & \\
\hline & Creative ways to pursue desires & Recognizing impact on others & \\
\hline \multirow[t]{13}{*}{ Purpose } & Initiative & Guilt & 3 to 6 years \\
\hline & Goal setting & Realistic goal setting & \\
\hline & Goal orientation (mastery) & $\begin{array}{l}\text { Goal orientation } \\
\text { (performance) }\end{array}$ & \\
\hline & Flexibility & $\begin{array}{l}\text { Resilience (when unable to } \\
\text { act) }\end{array}$ & \\
\hline & Self-advocacy & Avoiding narcissism, egotism & \\
\hline & Acting independently & Building relationships & \\
\hline & Being yourself & Considering others & \\
\hline & Developing passion & Developing balance & \\
\hline & Doing your best & Prosocial behavior & \\
\hline & Pursuit of individual needs/desires & $\begin{array}{l}\text { Pursuits to benefit the } \\
\text { common good }\end{array}$ & \\
\hline & Working alone & $\begin{array}{l}\text { Cooperation/working in } \\
\text { groups }\end{array}$ & \\
\hline & Positive striving & $\begin{array}{l}\text { Evaluative concerns } \\
\text { (perfectionism) }\end{array}$ & \\
\hline & Avoiding boredom & Waiting & \\
\hline \multirow[t]{2}{*}{ Competence } & Industry & Inferiority & 6 to 12 years \\
\hline & $\begin{array}{l}\text { Motivation-as linked to } V^{*} E \\
\text { (value and expectation; } \\
\text { recognizing value and expectation } \\
\text { of success; self-efficacy) }\end{array}$ & $\begin{array}{l}\text { Doing in order to develop } \\
\text { intrinsic motivation }\end{array}$ & \\
\hline
\end{tabular}

From Content-Based Curriculum for High-Abililty Learners, 3rd Ed.

Edited by Joyce VanTassel-Baska, Ed.D., and Catherine A. Little, Ph.D. ๑ 2017 Prufrock Press, Inc.

For W\&M ScholarWorks with permission of Prufrock Press Inc.

Written permission from the publisher required for any other use (http://www.prufrock.com/permissions). 


\section{TABLE 17.1, CONTINUED}

\begin{tabular}{|c|c|c|c|}
\hline \multirow[t]{10}{*}{$\begin{array}{l}\text { Essential } \\
\text { Strength }\end{array}$} & $\begin{array}{l}\text { Crisis-Positive } \\
\text { (Intrapersonal) }\end{array}$ & $\begin{array}{l}\text { Crisis-Negative } \\
\text { (Interpersonal) }\end{array}$ & $\begin{array}{l}\text { Approximate Age } \\
\text { of Initial Crisis }\end{array}$ \\
\hline & $\begin{array}{l}\text { Motivation (as linked to self- } \\
\text { determination theory): } \\
\text { Recognizing autonomy, } \\
\text { competence, relatedness needs }\end{array}$ & $\begin{array}{l}\text { Recognizing healthy balance } \\
\text { in self-determination needs }\end{array}$ & \\
\hline & Identifying interests & Trying new things & \\
\hline & Your social goals & Others' social goals & \\
\hline & Succeeding & Failing (positive) & \\
\hline & Outperforming others & $\begin{array}{l}\text { Sensitivity to being the } \\
\text { target of threatening upward } \\
\text { comparisons (STTUC) }\end{array}$ & \\
\hline & Self-advocacy & Supporting others' success & \\
\hline & Accepting/pursuing challenge & $\begin{array}{l}\text { Big Fish-Little Pond Effect } \\
\text { (BFLPE) }\end{array}$ & \\
\hline & Self-esteem & Social comparison & \\
\hline & Practice & Entity beliefs & \\
\hline \multirow[t]{9}{*}{ Fidelity } & Identity & Role Confusion & 12 to 20 years \\
\hline & $\begin{array}{l}\text { Knowing own/family/community } \\
\text { values }\end{array}$ & Learning about others' values & \\
\hline & Understanding own abilities & $\begin{array}{l}\text { Recognizing limitations in } \\
\text { abilities (social comparison) }\end{array}$ & \\
\hline & Career development & Multipotentiality & \\
\hline & Foreclosure & Moratorium, experimentation & \\
\hline & Authenticity & $\begin{array}{l}\text { Possible selves (effect on } \\
\text { competence when trying on } \\
\text { other selves) }\end{array}$ & \\
\hline & Crowd membership & $\begin{array}{l}\text { Changing or multiple } \\
\text { memberships }\end{array}$ & \\
\hline & Self-concept & Reputation & \\
\hline & Being yourself & $\begin{array}{l}\text { Information Management } \\
\text { Model (e.g., code-switching) }\end{array}$ & \\
\hline \multirow[t]{4}{*}{ Love } & Intimacy & Isolation & 20 to 40 years \\
\hline & $\begin{array}{l}\text { Identifying opportunities } \\
\text { commensurate with one's values }\end{array}$ & $\begin{array}{l}\text { Learning the requirements of } \\
\text { one's role in a group }\end{array}$ & \\
\hline & Leadership training & Servant leadership & \\
\hline & $\begin{array}{l}\text { Features of positive romantic } \\
\text { relationships }\end{array}$ & $\begin{array}{l}\text { Features of negative romantic } \\
\text { relationships }\end{array}$ & \\
\hline
\end{tabular}

From Content-Based Curriculum for High-Abililty Learners, 3rd Ed.

Edited by Joyce VanTassel-Baska, Ed.D., and Catherine A. Little, Ph.D. ๑ 2017 Prufrock Press, Inc.

For W\&M ScholarWorks with permission of Prufrock Press Inc.

Written permission from the publisher required for any other use (http://www.prufrock.com/permissions). 
Students need a sense of predictability and security in their world to have hope that they can be successful, whatever their definition of success. Lessons based on the intra- and interpersonal themes related to trust and mistrust can foster this sense of hope by helping students understand how they or others can or will respond to their needs. Such learning experiences should emphasize the supportive, responsive presentation of opportunities for talent development at early ages. Older students should have mentors and teachers who are responsive to their developing talents and to their psychological needs.

Building willpower. Erikson (1950/1995) described at length the infant's emerging awareness that she or he can act autonomously. The transition from a totally dependent newborn to an infant whose bite or grasp affects others has lasting consequences in the individual's beliefs about how positive his or her influence is on others. This early experience can become an important motivator for older children. When adults or older children harshly punish the bite or the grasp of an infant, she learns not to act on her own. Taken to the extreme in this negative direction, a child will come to be ashamed of her desire to act autonomously and will feel doubt over her ability to do so. At the other extreme, a child who is never reprimanded will come to believe he can act whenever and however he likes, becoming an annoyance or burden on those around him.

With regard to intrapersonal growth, it is useful to consider how to help students recognize autonomous activity. Lessons in helping them understand how to set goals - what would you do if there were no constraints? - should be presented along with lessons in how to put their goals into a relational perspective. They must have an appropriate amount of shame and doubt about pursuing activities that impinge unfairly on those around them. Practicing drums for days on end may be enjoyable and lead to excellent drumming skills, but the negative effect on those nearby can be severe. Recognizing that effect may encourage the drummer to invest in soundproofing or earplugs, making his or her pursuit more acceptable to others. Rather than making the budding musician feel ashamed of the desire to bang away, a better response is attempting to find ways to pursue the desire for drumming while minimizing the effects on others.

Learners can come to understand how to honor their desires to act autonomously within a social context, because it is important to learn how to work independently but also how to function cooperatively. Persistence is extremely important to talent development, but feeling an appropriate amount of shame and doubt in one's pursuits may lead to creative alternative paths that foster, rather than damage, relationships. Students need willpower to maximize their potential. Lessons to support its development should address the balance 
between acting autonomously and feeling ashamed or doubtful about pursuing desires.

Finding purpose. An important component of the school-based conception of giftedness (Cross \& Coleman, 2005) is students' sustained high level of achievement. Students who are able to create and follow through on their own ideas are more likely to exhibit this sustained achievement. According to Erikson (1950/1995), it is necessary that students learn how to pursue their dreams within a social context. The countervailing guilt he described is associated with a concern for others that must accompany initiative. Pursuit of plans one has created can best be accomplished with the support of others. For school-aged students with high potential and high achievement, this means the cooperation of peers and support from adults. Like the child determined to act autonomously, the gifted student who can imagine great things must develop an awareness of the effects of his plans on others. The child who wants expensive special lessons that require a parent to take a second job may not need to know the details of the situation, but must have an awareness and a certain amount of guilt about the parent's sacrifice. The child who wants to create a food bank to feed the homeless in her or his community will need adult and peer support to make the dream a reality.

With their exceptional abilities, school-aged students with gifts and talents should be supported in their pursuit of grand ideas. At the same time, their psychological well-being and social relationships depend on the favorable ratio they develop between pursuing their initiative and experiencing an appropriate amount of guilt. This delicate balance is especially significant among students who are capable of great accomplishments. It is imperative that they settle on a ratio that allows them to maximize their potential, while maintaining important relationships. In one example, Peine and Coleman (2010) found that gifted students in their study experienced boredom as unpleasant, but accepted the necessity of waiting for others to catch up and developed strategies for dealing with the boredom (e.g., reading ahead). Although it is preferable that schools appropriately challenge all students, those in Peine and Coleman's study found a favorable ratio through their strategies for avoiding boredom.

Research on perfectionism suggests that an unfavorable ratio, skewed toward guilt, will have negative consequences. Socially prescribed perfectionism (Hewitt \& Flett, 1991) exists when one believes that others expect her or him to perform at unreasonably high levels. In other words, one feels guilty because of perceptions of others' expectations. Although striving for high levels of performance has not been found to be associated with negative psychological outcomes, concerns over evaluation have (Speirs Neumeister, 2015). Guilt over what one can imagine doing will result in a loss of purpose. It is important for students to learn how to interpret and put others' expectations (and per- 
ceptions of others' expectations) in perspective and to reduce their concerns about being evaluated. Lessons in activities such as goal setting, self-advocacy, and working independently should be complemented by lessons in prosocial behavior, relationship building and cooperation.

Developing competence. Children in school are learning to sublimate the joy they once took in play with the new experience of learning the tools of their culture. As they participate in these new activities, they develop a sense of industry. Working offers opportunities for successful productivity, which can lead to satisfaction. Most gifted students are likely to do well in these endeavors, and many are found and identified for gifted services because of their success. Even as they are learning how well they can perform, students are looking around them to see how they compare to others. When they are among other high-ability students, they could easily develop feelings of inferiority. This phenomenon, named the Big-Fish-Little-Pond Effect (BFLPE), has been well studied (see Dai \& Rinn, 2008, for a review). More likely is that they will perform better than their peers. In this circumstance, they may develop a sensitivity to being the target of threatening upward comparisons (Exline \& Lobel, 1999). In the psychosocial arena, these phenomena need attention (Cross, 2015). In the development of competence, Erikson (1950/1995) proposed that well-being depends on a favorable ratio between the pleasure one takes in work and the sense of inferiority one feels when others are more capable.

In addition to lessons on outperformance and social comparison, the lessons recommended to support the strength of competence emphasize supporting motivation. Motivation depends on recognizing the value or utility of engagement in an activity, along with an expectation of success (Wigfield \& Eccles, 2000). Even when students are not motivated to engage in an activity, it is possible to change their attitudes. Ryan and Deci (2000) described the path from amotivation to intrinsic motivation that may develop simply through engagement in a task - at first because others expect it, but, over time and with success, because doing the activity becomes integrated with self-concept. Self-determination theory (Ryan \& Deci, 2002) is based on the idea that individuals are motivated to fulfill three primary psychological needs: autonomy, competence, and relatedness. Students must learn how to recognize these needs in themselves and others. Well-being is affected by an unbalanced pursuit of need fulfillment. The talented student who spends a disproportionate amount of time practicing an instrument, for example, may suffer in his or her need for relatedness. If that practice time happens at the demand of parents or teachers, a student's autonomy needs may suffer. As they take pleasure in developing competence, students must maintain a balanced lifestyle that considers their psychological and social needs as well. 
Motivation may also be affected by entity beliefs. Dweck (1999) found that students who believed their academic abilities were innate characteristics, an entity they possessed or did not, lost motivation for a task that was challenging. Such self-beliefs can be challenged in lessons that emphasize the change in abilities that can come with practice. When students recognize the role of effort in their success, they can stay motivated in the face of failure. In fact, it is helpful for students who show high levels of performance to experience failure, so they can understand how to bounce back. So long as the failures do not have severe consequences, they can be seen as positive opportunities for developing competence.

In keeping with a school-based conception of giftedness, schools should offer opportunities for students to explore many areas of interest when they are young. As they find domains that pique their interest, motivation can be sustained through development of increasing competence in that domain. Erikson $(1950 / 1995,1968)$ proposed that it is in this stage that children are most open to the adult models of various roles in society. Schools that provide highly qualified teachers and mentors in a variety of domains to older students, in particular, will support continued motivation and expertise. By simultaneously attending to their psychological and social needs, schools can foster competence in students.

Acquiring fidelity. Achieving an identity, a belief in one's sameness and continuity (Erikson, 1968), is the crisis of adolescence. Before adolescence, children are becoming-learning who they are in relation to others, learning what they can do and what others expect of them. As they experience adolescence, they know more of what they are capable of and are deciding what they will do with that ability. Some will settle easily into predetermined roles, while others will want to explore more options (Marcia, 1966). Having expertise in a domain will direct some students towards an identity within the domain. Some students with gifts and talents are highly capable in more than one domain and this multipotentiality can lead to role confusion (Rysiew, Shore, \& Leeb, 1999; Sajjadi, Rejskind, \& Shore, 2001). Having a clear understanding of one's values can help resolve confusion in identity formation (Kerr, 2012). Gifted students should have many opportunities to explore possible talent development trajectories. Some trajectories occur later than others (Subotnik et al., 2011), and it is critical that students not settle on one trajectory that may preclude other, equally viable and interesting, options. Guest speakers, classes in career development, and wide exposure to the many options available to them in a modern society will be important to their knowledge base.

Adolescents are not only thinking about who they are in terms of a career path. They are also identifying themselves in relation to their peers. Adolescent peer groups are powerful shapers of identity. The status peers assign to the 
various "crowds" (e.g., the Jocks, the Freaks, the Brains, etc.) can motivate students to pursue crowd membership by adopting preferred dress, musical styles, and activities (Cross, 2012). It is important for students to learn about the crowd phenomenon and the negative significance of affiliating with a crowd that places a low value on academic achievement.

In their search for the sameness and continuity of a settled identity, adolescents may not recognize the necessity of information management in social situations. Managing information about one's outperformance of peers may be critical to maintaining friendships. How can gifted students be true to themselves while recognizing the effects of their behavior on others? Cross, Coleman, and Terhaar-Yonkers (1991) found that many gifted high school students would lie rather than expose their better performance to peers. Verbally gifted students tend to have more social difficulties than those who are mathematically gifted (Lee, Olszewski-Kubilius, \& Thomson, 2012; Peairs, 2010). It may be beneficial for these students to learn how to code-switch, a phenomenon identified in linguistics, where individuals speak in different registers to meet the communication needs of diverse communities (Bell, 1984; Ladegaard, 1995). In their fear of losing the continuity of self they have been struggling for, they may see this important skill as a challenge to identity. These lessons can contribute to students' identity formation and, hence, to fidelity.

Commitment through love. In their search for fidelity, adolescents often explore relationships, both romantic and ideological. Experimenting with appearances, activities, boyfriends and girlfriends, different religions and ideologies - these are examples of the search for identity. The outcome of that process, a secure sense of self, sets the stage for the next crisis. Only when one has achieved fidelity can she or he make a real commitment that requires sacrifices of different kinds. During the crisis of intimacy versus isolation, individuals attempt to connect with others in a meaningful, lasting way. Such commitments require sacrifices of time and preferred activities as time is spent in the relationship. A commitment to an organization (e.g., work, club, political party, etc.) or a romantic partner requires similar sacrifices.

Erikson (1950/1995) proposed that the crisis of intimacy versus isolation would not be faced until early adulthood. Anecdotal evidence suggests some gifted students may be ready to make such serious commitments earlier than their peers. The essential strength of love is analogous to the passion Coleman (2012) described. Some students are consumed by their passions, sacrificing time with peers, activities, and even eating to pursue their love of learning. When the very young student experiences a consuming passion, it may be more of an obsession, because, developmentally, she or he is not capable of "the ethical strength to abide by such commitments" (Erikson, 1950/1995, p. 237). 
Only by experiencing the earlier crises is intimacy in the Eriksonian sense possible.

\section{Linking the SPCM and the Integrated Curriculum Model}

VanTassel-Baska's Integrated Curriculum Model (ICM; VanTassel-Baska, 2011) recommends a process/product dimension in curriculum for gifted students. This dimension of the ICM may also be seen in the SPCM, as it can provide students with scaffolds or processes that facilitate the development of high-level, original products. A wide range of products relating to such processes are possible, reflecting the fact that what would be considered high level varies with the age of the student, and the SPCM should be used over a wide range of ages or school grade levels to optimize development. For example, for younger students, knowledge of psychosocial skills, their effects, and participation in teacher-designed activities that facilitate development are high-level activities. For older students, high-level products would be more complex and include metacognitive exercises about their own responses in social situations, analyses of the psychosocial skills that are needed to develop talents (of other gifted individuals or their own talents), or creating plans for personalized psychosocial skill development based on self-analyses.

The SPCM uses the SIP model (Figure 17.1) as a scaffold for students as they conduct analyses of social situations and potential responses. The version of the SIP in Figure 17.1 is appropriate for older students and may be simplified for younger students, as seen in Figure 17.2. After students are taught how to use the SIP to analyze a situation and are provided opportunities to practice, such as in class discussions of vignettes about a gifted student in various social situations, the students should be able to apply the SIP to other situations.

Developing students' knowledge of advanced content, such as Erikson's (1950/1995) crises and the use of the SIP, supports positive psychosocial development. Use of the intrapersonal aspects of Erikson's model (found on the center-left side of Table 17.1) as a metacognitive lens encourages the development of self-knowledge. The SIP is also a useful model for facilitating interpersonal learning. The activities found on the center-right side of Table 17.1 emphasize such interaction.

Appropriate teaching strategies for these lessons include student research, bibliotherapy, and reflection. School counselors can teach strategies for such topics as self-talk and goal setting, for example. Many formats are possible for student products, including written reports, multimedia artifacts, journals, or creative writing that emphasizes self-knowledge.

All-important in the processing of social information is the content of the "database" at the center of the SIP figure. The goal of most assignments will 


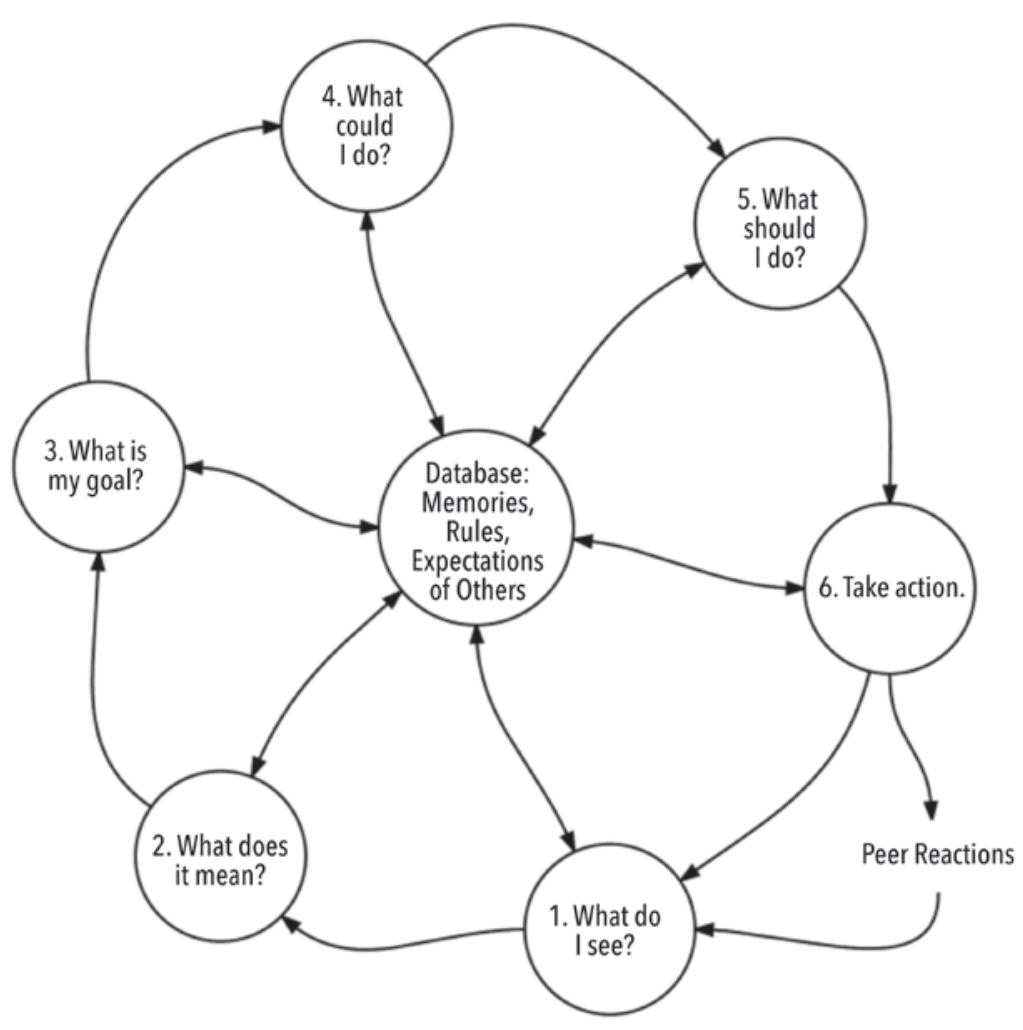

Figure 17.2. Simplified Social Information Processing Model for younger students.

be to build the database, filling it with information about the self and others. Students' analyses and development of their own databases are high-level metacognitive activities. The database is constantly referred to throughout the processing of social information. Interpretation of cues is done from experience. For example, multiple studies have found that aggressive youths often misinterpret facial expressions as hostile, leading to inappropriate behavioral responses (e.g., Bowen \& Dixon, 2010; Fairchild, Van Goozen, Calder, Stollery, \& Goodyer, 2009). By filling their databases with correct attributions for various facial expressions through intensive cognitive retraining, researchers were able to reduce aggressive behaviors (Penton-Voak et al., 2013).

Through experiencing lessons based on the SPCM, students with gifts and talents will be developing a database that can be referred to for interpretation of cues, retrieval of social goals, and possible responses from which to choose to act. The activities found on the right-hand side of Table 17.1 emphasize social interaction. Guidance and support related to the experience of developing and pursuing goals within a social context will help students cope with the 
situations they face. An analysis with the SIP tied to the initiative versus guilt crisis and similar situations can help students add guidelines for goal-setting into their databases, such as the importance of considering others affected in the pursuit of one's goals.

Clarification of social goals is a challenging but critical step in interactions with others. People have a variety of social goals (Cross et al., 1991; Ojanen, Grönroos, \& Salmivalli, 2005). They may wish to increase their status or power or to build relationships. These goals will lead to different response options in social interactions. Making students aware of their goals and the possible goals of others can be helpful in developing their own responses. The SIP can be readily applied, with simpler and more structured activities for younger students and greater complexity for older ones. The appendix to this chapter has an example of assignments for elementary and secondary students.

Offering advanced content through the SPCM. Students gifted in academic domains should have opportunities to progress rapidly in many learning situations, a feature of the ICM curriculum and most other models found to be effective with gifted learners. Some academically gifted students will also have strong psychosocial skills, but many will not. Erikson (1968) built his theory on the assumption of an epigenetic principle: "anything that grows has a ground plan, and ... out of this ground plan the parts arise, each part having its time of special ascendancy, until all parts have arisen to form a functioning whole" (p. 92). He continued, "The parts leading to a whole person are all present in the individual throughout the lifespan," but "each [part] comes to its ascendance, meets its crisis, and finds its lasting solution ... toward the end of the stages" (p. 95). It does not make sense to build an affective curriculum that attempts to move children through stages for which they are not prepared in other ways. For example, adolescents searching for identity should not be encouraged to commit to an intimate relationship (i.e., with a person or ideology) until they have successfully negotiated fidelity.

In keeping with Erikson's (1950/1995) theory, the SPCM does not specifically have faster learning as a goal. Some students, however, will be advanced of their peers in the psychosocial domain and will need to progress more quickly through the curriculum or with materials that are more advanced. For example, the content of the curriculum may be advanced through use of advanced reading materials, such as Erikson's own work and authentic research articles related to the theory. In making decisions about pace and level of materials, teachers must consider each child's knowledge and appropriately plan the lessons of the SPCM to meet students' idiosyncratic needs. Tools for a diagnostic-prescriptive (VanTassel-Baska, 1986; VanTassel-Baska \& Wood, 2010) approach must be developed to accompany lessons and units developed with the SPCM. 
Despite their exceptional academic abilities, not all gifted students are socially adept. Even the most advanced mathematician or creative writer may need a basic lesson in identifying internal and external resources (trust vs. mistrust) or how to pursue individual needs/desires and the common good (initiative vs. guilt). Examining these crises with an academic lens may allow students to develop an understanding of some of their social situations and to develop strategies for managing them. A lesson related to the earliest crisis of trust versus mistrust or initiative versus guilt is appropriate for a high school student. Those who have a favorable ratio will be reminded of the balance and those with an unfavorable ratio can reframe their unhealthy perspectives. The SPCM is appropriate for students of all ability levels, but gifted students may be different from their peers in their psychosocial capacity and the timing of the onset of different crises. Some of their interpersonal relationships will be tinged with awe, expectations, and sometimes envy, and students may have difficulty understanding and managing these relationships. By gaining an early understanding of the association between their initiative and the guilt they feel from its effect on others, however, students may be able to develop strategies for appropriate and effective social responses.

Similarly, the curriculum to be offered to older or psychosocially precocious students may include lessons incorporating experiences faced uniquely by academically advanced learners. For example, the expectation that they will use their talents to help peers can be a burden, yet can also be a means of building relationships with peers. Students who are less successful in school do not face this expectation. A lesson in working alone and working cooperatively (initiative vs. guilt) can provide advanced content by emphasizing this challenge.

Providing a continuum of advanced skills. Complexity and depth in SPCM lessons represent another way to provide a learning experience that is differentiated to respond to advanced learners. Biographies can increase in complexity for more mature students, and the expectation to interpret biographies from the lens of Erikson's theory provides challenge as students read. Discussion groups can take on more difficult topics, including the ethics underlying decisions that tend toward one or the other end of each crisis or of differing social goals in the SIP. Further, in another area of linkage to the ICM, the crises can be examined at a conceptual level, with connections to other kinds of conflict or crisis as a central focus.

Examination of the components of the SIP can easily be done at a simple, moderate, or highly complex level. At the most basic level, all gifted learners need an understanding of how the process works. More importantly, their abilities to enter, interpret, and respond effectively to social interactions are critical to the successful development of their talents. Lessons based on the SIP can enhance these abilities, increasing their self-understanding, making them 
aware of their needs, and contributing to their cognitive and affective growth (NAGC, 2010).

One reason for developing an affective curriculum for gifted learners is to address skills with which students struggle in the psychosocial arena. Although by definition, these students excel or have the potential to excel in academics, some-perhaps many-will require support in psychosocial areas. Differentiation of instruction among widely varying ability levels even within a group of advanced learners will be critical to a curriculum's success. Implementation of the SPCM may be an excellent opportunity for students to learn among peers who may not have the same level of academic skills, but who are at a similar or higher level in their psychosocial skills. Varied grouping arrangements can give these students important opportunities to gain a perspective on their peers' exceptional nonacademic abilities.

\section{Conclusion}

Through applying Erikson's comprehensive theory, the SPCM addresses gifted students' intrapersonal and interpersonal knowledge, beliefs, attitudes, and behaviors, contributing to their self-understanding and acceptance, and fostering their positive interactions with others. By assisting in their psychological and social development, schools will enhance the abilities of learners with gifts and talents to effectively approach and respond to talent development opportunities and challenges.

\section{Key Points Summary}

$>$ Affective curriculum for the gifted requires teachers to integrate the psychosocial dimension of curriculum into all that is taught in schools.

$>$ The development of personal and social skills is essential to gifted learners and may be attained through implementation of a model called SPCM, based on Erikson's theory of psychosocial development. 
D A Social Information Processing Model (SIP) may be applied to personal-social situations that students experience to help students interpret those experiences at each stage of psychosocial development.

$>$ There is a distinct overlay in the intent of the SPCM and the ICM with respect to providing advanced content, higher level processes, and the development of advanced products for the gifted.

$>$ Psychosocial development for students with gifts and talents requires the deliberate application of an affective model to be used by schools.

\section{References}

Bell, A. (1984). Language style as audience design. Language in Society, 13, 145-204.

Bowen, E., \& Dixon, L. (2010). Concurrent and prospective associations between facial affect recognition accuracy and childhood antisocial behavior. Aggressive Behavior, 36, 305-314.

Coleman, L. J. (2012). Lived experience, mixed messages, and stigma. In T. L. Cross \& J. R. Cross (Eds.), Handbook for counselors serving students with gifts and talents (pp. 371-391). Waco, TX: Prufrock Press.

Conduct Problems Prevention Research Group. (2004). The Fast Track experiment: Translating the developmental model into a prevention design. In J. B. Kupersmidt \& K. A. Dodge, Children's peer relations: From development to intervention (pp. 181-208). Washington, DC: American Psychological Association.

Crick, N. R., \& Dodge, K. A. (1994). A review and reformulation of social information-processing mechanisms in children's social adjustment. Psychological Bulletin, 115, 74-101.

Cross,J.R. (2012). Crowds.In R.J. R. Levesque (Ed.), Encyclopedia of Adolescence (pp. 573-580). New York, NY: Springer.

Cross, J. R. (2015). Gifted children and peer relationships. In M. Neihart, S. I. Pfeiffer, \& T. L. Cross (Eds.), The social and emotional development of gifted children: What do we know? (2nd ed., pp. 41-64). Waco, TX: Prufrock Press.

Cross, T. L., \& Coleman, L. J. (2005). School-based conception of giftedness. In R. J. Sternberg \& J. E. Davidson (Eds.), Conceptions of giftedness (2nd ed., pp. 52-63). Cambridge, England: Cambridge University Press. 
Cross, T. L., Coleman, L. J., \& Terhaar-Yonkers, M. (1991). The social cognition of gifted adolescents in schools: Managing the stigma of giftedness. Journal for the Education of the Gifted, 15, 44-55.

Dai, D. Y., \& Rinn, A. N. (2008). The big-fish-little-pond effect: What do we know and where do we go from here? Educational Psychological Revierw, 20, 283-317.

Dweck, C. S. (1999). Self-theories: Their role in motivation, personality, and development. Philadelphia, PA: Psychology Press.

Erikson, E. (1995). Childhood and society. London, England: Vintage Press. (Original work published 1950)

Erikson, E. (1968). Identity: Youth and crisis. New York, NY: W. W. Norton.

Exline, J. J., \& Lobel, M. (1999). The perils of outperformance: Sensitivity about being the target of a threatening upward comparison. Psychological Bulletin, 125, 307-337.

Fairchild, G., Van Goozen, S. H. M., Calder, A. J., Stollery, S. J., \& Goodyer, I. M. (2009). Deficits in facial expression recognition in male adolescents with early-onset or adolescence-onset conduct disorder. Journal of Child Psychology and Psychiatry, 50, 627-636.

Freud, S. (1923). The ego and the id. New York, NY: W.W. Norton.

Hewitt, P. L., \& Flett, G. L. (1991). Perfectionism in the self and social contexts: Conceptualization, assessment, and association with psychopathology. Journal of Personality and Social Psychology, 60, 456-470.

Jahoda, M. (1950). Toward a social psychology of mental health. In M. J. E. Benn (Ed.), Symposium on the healthy personality (Supplement II: Problems of infancy and childhood, transactions of fourth conference, March, 1950). New York, NY: Josiah Macy, Jr. Foundation.

Kazdin, A. E. (2003). Problem-solving skills training and parent management training for conduct disorder. In A. E. Kazdin \& J. R. Weisz (Eds.), Evidence-based psychotherapies for children and adolescents (pp. 241-262). New York, NY: Guilford Press.

Kerr, B.A. (2012). Developmental issues for gifted and creative girls: Milestones and danger zones. In T. L. Cross \&J. R. Cross (Eds.), Handbook for counselors serving students with gifts and talents (pp. 315-331). Waco, TX: Prufrock Press.

Ladegaard, H. J. (1995). Audience design revisited: Persons, roles and power relations in speech interactions. Language E Communication, 15, 89-101.

Lee, S-Y., Olszewski-Kubilius, P., \& Thomson, D. T. (2012). Academically gifted students' perceived interpersonal competence and peer relationships. Gifted Child Quarterly, 56, 90-104. 
Lochman, J. E., \&Wells, K. C. (2004). The Coping Power Program for preadolescent aggressive boys and their parents: Outcome effects at the 1-year follow-up. Journal of Consulting and Clinical Psychology, 72, 571-578.

Marcia, J. (1966). Development and validation of ego-identity status. Journal of Personality and Social Psychology, 3, 551-558.

National Association for Gifted Children. (2010). Pre-K to grade 12 gifted programming standards. Retrieved from http://www.nagc.org/ resources-publications/resources/national-standards-gifted-and-talentededucation/pre-k-grade-12

Ojanen, T., Grönroos, M., \& Salmivalli, C. (2005). An interpersonal circumplex model of children's social goals: Links with peer-reported behavior and sociometric status. Developmental Psychology, 41, 699-710.

Peairs, K. F. (2010). The social world of gifted adolescents: Sociometric status, friendship and social network centrality (Doctoral dissertation). Retrieved from Proquest Dissertations and Theses. (UMI No. 3469001)

Peine, M., \& Coleman, L. (2010). The phenomenon of waiting in class. Journal for the Education of the Gifted, 34, 220-244.

Penton-Voak, I. S., Thomas, J., Gage, S. H., McMurran, M., McDonald, S., \& Munafò, M. R. (2013). Increasing recognition of happiness in ambiguous facial expressions reduces anger and aggressive behavior. Psychological Science, 24, 688-697.

Ryan, R. M., \& Deci, E. L. (2000). Self-determination and the facilitation of intrinsic motivation, social development, and well-being. American Psychologist, 55, 68-78.

Ryan, R. M., \& Deci, E. L. (2002). Overview of self-determination theory: An organismic dialectical perspective. In E. L. Deci \& R. M. Ryan (Eds.), Handbook on self-determination research (pp. 4-33). Rochester, NY: The University of Rochester Press.

Rysiew, K. J., Shore, B. M., \& Leeb, R. T. (1999). Multipotentiality, giftedness, and career choice: A review. Journal of Counseling and Development, 77, 423-430.

Sajjadi, S. H., Rejskind, F. G., \& Shore, B. M. (2001). Is multipotentiality a problem or not? A new look at the data. High Ability Studies, 12, 27-43.

Speirs Neumeister, K. (2015). Perfectionism in gifted children. In M. Neihart, S. I. Pfeiffer, \& T. L. Cross (Eds.), The social and emotional development of gifted children: What do we know? (2nd ed., pp. 29-40). Waco, TX: Prufrock Press.

Subotnik, R. F., Olszewski-Kubilius, P., \& Worrell, F. C. (2011). Rethinking giftedness and gifted education: A proposed direction forward based on psychological science. Psychological Science in the Public Interest, 12(1), 3-54. doi:10.1177/1529100611422045 
VanTassel-Baska, J. (1986). Effective curriculum and instructional models for the gifted. Gifted Child Quarterly, 30, 164-169.

VanTassel-Baska, J. (2011). Introduction to the ICM. In J. VanTassel-Baska \& C. A. Little (Eds.), Content-based curriculum for high-ability learners (2nd ed., pp. 9-32). Waco, TX: Prufrock Press.

VanTassel-Baska, J., Cross, T. L., \& Olenchak, F. R. (Eds.). (2009). Socialemotional curriculum with gifted and talented students. Waco, TX: Prufrock Press.

VanTassel-Baska, J., \& Wood, S. (2010). The integrated curriculum model (ICM). Learning and Individual Differences, 20, 345-357.

Wigfield, A., \& Eccles, J. S. (2000). Expectancy-value theory of achievement motivation. Contemporary Educational Psychology, 25, 68-81. doi:10.1006/ ceps.1999.1015

\section{Appendix Sample Interpersonal SIP Assignments}

\section{For Elementary-Aged Gifted Students}

Objective: Students will build skill in encoding cues in a social interaction.

1. You would like to invite your friend ___ to your house to play. You ask if he/she can come over. What do you notice about reaction? List as many things as possible. (Answer should include such components as eye contact, facial expression, body language, others present, 's current activity, etc.)

2. Follow up the observations with discussion of multiple possible interpretations of different aspects of the response, with connection to how the evidence may be interpreted in different ways depending on the circumstances.

\section{For Secondary-Aged Gifted Students}

Objective: Students will recognize the social information processing required to develop an appropriate response.

1. Select a goal from your list of long-term goals.

2. Identify who in your life needs to know about this goal in order to make it happen. 
3. Formulate a request to one person who can help you with the goal.

4. Imagine that you have just made this request to the individual.

5. What should you attend to in the individual's response?

6. How should you respond if the response is positive? Negative?

Discuss responses. Consider role-playing different possible responses and reactions, with discussion of multiple interpretations of the circumstances. 